\title{
TERAPI BERMAIN ENGLISH GAMES UNTUK MENINGKATKAN KEMAMPUAN KOGNITIF ANAK PRASEKOLAH
}

\author{
Eka Adimayanti ${ }^{1}$, Dewi Siyamti ${ }^{2}$ \\ ekaadimayanti05@gmail.com \\ Prodi D3 Keperawatan Fakultas Keperawatan Universitas Ngudi waluyo
}

\begin{abstract}
ABSTRAK
Anak memiliki pertumbuhan dan perkembangan yang pesat pada awal-awal kehidupan dimana proses itu tidak dapat diulang kembali sehingga kualitas perkembangan anak dimasa depannya ditentukan oleh stimulasi yang diperolehnya sejak dini. Anak Usia prasekolah memasuki tahap perkembangan pra operasional dimana mempunyai karakteristik menonjol anak telah mengkombinasi dan mentransformasi informasi, mampu mengemukakan alasan dan menyatakan ide, mulai mengerti hubungan sebab akibat dan mempunyai cara berfikir egosentris. Kegiatan Pengabdian kepada Masyarakat dengan Judul "Terapi Bermain (English Games) dapat meningkatkan kemampuan kognitif anak Prasekolah.Adapun tujuan dari kegiatan ini adalah untuk meningkatkan kemampuan kognitif anak TK IT Cahaya Ummat.Metode yang digunakan adalah dengan terapi bermain English games.Kegiatan tersebut bermain dengan English games. Hasil yang didapatkan adalah kemampuan anak dalam berfikir secara kognitif melalui tebak gambar, tebak huruf, tebak warna, tebak kata, menyebutkan nama nama hari, menyebutkan angka, menyebutkan nama buah, menyebutkan anggota tubuh, sehinga anak mampu memungpulkan banyak kosakata baru dalam permainan kartu bahasa inggris. Beberapa anak ada sudah mulai belajar berkomunikasi dengan menggunakan bahasa inggris.

Kata Kunci :Terapi bermain, English games, kemampuan kognitif
\end{abstract}

\begin{abstract}
Children have rapid growth and development in early life where the process cannot be repeated so that the quality of children's development in the future is determined by the stimulation they get early. Preschoolers enter the preoperational development stage where they have prominent characteristics. Children have combined and transformed information, are able to express reasons and express ideas, begin to understand causal relationships and have egocentric ways of thinking. Community Service Activities with the title "Play Therapy (English Games) can improve cognitive abilities of Preschoolers. The purpose of this activity is to improve the cognitive abilities student of TKIT Cahaya Ummat. The method used is to play English games therapy. The activity is playing with English games. The results obtained are the ability of children to think cognitively through guessing pictures, guessing letters, guessing colors, guessing words, mentioning names of days, mentioning numbers, mentioning names of fruits, mentioning limbs, so that children are able to accumulate a lot of new vocabulary in language card games English. Some children have started to learn to communicate using English.
\end{abstract}

Keywords: Play therapy, English games, cognitive abilities 


\section{PENDAHULUAN}

Anak prasekolah adalah mereka yang berusia aniara 3-6 tahun menurut.Mereka biasanya mengikuti program prasekolah dan kinderganten. Sedangkan di Indonesia. umumnya mereka mengikuti program Tempat Penitipan Anak (3 bulan - 5 tahun) dan Kelompok bertnain (usia 3 tahun). Sedangkan pada usia 4-6 tahun biasanyn mereka mengikuti program Taman Kanak-Kanak. Usia prasekolah adalah usia yang rentan bagi anak. Pada usia ini anak mempunyai sifat imitasi atau meniru terhadap apapun yang telah dilihatnya.[1]

Menurut Jean piaget, bahwa perkembangan intelektual anak usia 5-6 tahun termasuk fase praoperasional, yaitu masa prasekolah. Pada masa ini anak belum bisa membedakan dengan tegas antara perasaan dan motif pribadinya dengan realita dunia luar, sehingga pada taraf ini kemungkinan untuk menyampaikan konsep-konsep tertentu kepada anak masih terbatas.[2] Para ahli psikologi anak mengatakan bahwa kreativitas anak akan dimulai sejak usia 3 tahun dan mencapai puncaknya sampai umur 4,5 tahun. Operasional pendidikan bagi anak-anak usia dini dan anak-anak pra-sekolah (TK) akan lebih bermakna jika dilakukan melalui metode pendidikan yang menyenangkan, edukatif, sesuai dengan minat dan bakat serta kebutuhan pribadi anak. Oleh karena itulah mereka butuh permainan sebagai media pendidikan di dalam pembelajaran di sekolah. Alat bermain tidak harus mahal, unsur mendidiklah yang harus diutamakan, lebih jelas lagi jika dalam menyampaikan materi pelajaran dengan pendekatan bermain sambil belajar.[3]

Bermain merupakan aktivitas yang penting dilakukan anak-anak, sebab dengan bermain anak-anak akan bertambah pengalaman dan pengetahuannya. Melalui bermain anak memperoleh pelajaran yang mengandung aspek perkembangan kognitif, emosi dan perkembangan kreativitas.bermain adalah kegiatan yang menyenangkan, bersifat pribadi, berorientasi proses, bersifat fleksibel, dan berefek positif. Bermain juga dapat diartikan sebagai kegiatan yang dilakukan demi kesenangan dan 
tanpa mempertimbangkan hasil akhir.Kegiatan tersebut dilakukan secara suka rela, tanpa paksaan atau tekanan dari pihak luar.[4] Bermain membantu anak membangun konsep dan pengetahuan.Anak-anak tidak membangun konsep atau pengetahuan dalam kondisi yang terisolasi, melainkan melalui interaksi dengan orang lain.[5] Bermain membantu anak mengembangkan kemampuan berpikir abstrak. Proses ini terjadi ketika anak bermain peran dan bermain pura-pura. Vygotsky menjelaskan bahwa anak sebenarnya belum mampu berpikir abstrak.Bermain mendorong anak untuk berpikir kreatif.[6]

Permainan untuk anak prasekolah dapat berupa game edukasi. Beberapa jenis game edukasi antara lain: kids Preschool Puzzles, Educational games for kids, $A B C$ preschool.Game ini akan sangat menarik untuk anak-anak khususnya anak yang baru menapaki usia prasekolah. Kids Preschool Puzzles menyajikan sebuah potonganpotongan dengan warna yang bervariasi untuk kemudian dicocokan ke dalam gambar yang kosong.Game bernama ABC Kids ini memiliki konsep dan mengkhususkan diri dalam mengedukasi anak-anak untuk mengenal huruf saja. Tidak ada konsep lainnya dan hal tersebut membuat game ini menjadi lebih fokus ke dalam satu bahasan saja.[7]

Konsep terapi bermain ini sangat cocok untuk meningkatkan perkembangan kognitif pada anak prasekolah. Untuk itu penulis tertarik untuk melakukan kegiatan pengabdian kepada masyarakat dengan judul terapi bermain English games untuk meningkatkan kemampuan kognitif anak usia prasekolah"

\section{METODE}

Sasaran dan Metode (bentuk) kegiatan yang digunakan adalah siswa TKIT Cahaya Ummat kelas A dan B. Metode yang digunakan terapi bermain dengan English fun. Pengabdian dilakukan pada Bulan Desemberi 2019- Februari 2020 mulai jam 08.00 wib samapi selesai. Tempat kegiatan di TKIT Cahaya Ummat.Sarana yang digunakan adalah 
ruang kelas ruang kelas TK A dan TK B, Ruang Perteman. Alat yang digunakan meliputi : 10 set alat bermain, alat tulis, sound system, mikrophon.

Kepala sekolah, Wakil Kepala Sekolah,, Guru kelas TKIT Cahaya Ummat, Mahasiswa dan Tim Pelaksana. Kendala yang dihadapi: pada anak hasil perkembangan kognitifnya delay masih membutuhkan waktu khusus dan stimulasi yang terus menerus.Penilaian dan instrumen yang digunakan untuk mengetahui keberhasilanberdasarkan questioner KPSP aesuai usia anak

\section{HASIL DAN PEMBAHASAN}

\section{A. HASIL}

Pengabdian dilaksanakan pada bulan Desember 2019 sampai dengan bulan Februari 2019 bertempat di TKIT Cahaya Ummat.Siswa yang mengikuti kegiatan berjumlah 54 siswa.

Pelaksanaan pengabdian dilakukan ke masing-masing kelas sesuai dengan jadwal yang telah ditentukan.Sebelum kami memberikan materi kepada siswa, kami melakukan apersepsi terlebih dahulu kepada guru kelas masing masing.Setelah melakukan apersepsi dengan guru kelas kami melanjutkan intervensi. Intervensi yang pertama yaitu Tim Melakukan pemeriksaaan perkembangan dengan menggunakan kuesiner KPSP sesuai usia anak di kelas masing masing.

Langkah yang selanjutnya melakukan terapi bermain English games.Melaksanakan evaluasi dengan melakukan pemeriksaan perkembangan kembali terutama untuk kemampuan kognitif anak. Hasil dari evaluasi kemampuan kognitif anak usia prasekolah TKIT Cahaya Ummat, terdapat 1 anak yang mempunyai keterlambatan kognitif dan memerlukan stimulasi secara terus menenerus untuk meningkatkan kemampuan kognitif anakat tersebut. Pada saat dilakukan English games, anak mampu menyebutkan deretan angka, nama buah, nama anggota badan, dan nama hari melalui permaianan kartu. 


\section{B. PEMBAHASAN}

Perkembangan kognitif anak usia dini adalah kemampuan cara berpikir anak usia dini dalam memahami lingkungan sekitar sehingga pengetahuan anak bertambah.[8] Dengan bermain anak dapat mengeksplorasi pengetahuan dan kemampuan sosialnya.Terapi bermain dengan menggunakan permainan dalam bahasa inggris merupakan pembelajaran yang kooperatif bagi anak prasekolah.Sesuai dengan teori perkembangan kognitif Lev Vygotsky.[8] Teori ini adalah teori yang sesuai dengan model pembelajaran kooperatif, yang terjadi interkasi social antara peserta didik dengan peserta didik dan peserta didik dan pendidik. Vygotsky yakin pembelajaran terjadi saat anak mengerjakan tugas-tugas "'zone of proximal development".

Belajar melelui permainan juga dapat meningkatkan kognitif anak. Hal ini sesuai dengan teori belajar yang disampaikan oleh Gestalt Teori yang berlaku untuk semua aspek pembelajaran manusia,seperti :Pengalaman tilikan (insight) Pembelajaran yang bermakna (meaningful learning) Perilaku bertujuan (purposive behavior) Prinsip ruang hidup (life space) Transfer dalam Belajar Jean Piaget (Jean Piaget 2016) Pengalaman adalah factor penting yang mendasari proses berfikir anak.

Pengalaman yang hanya melibatkan mata berbeda dengan pengalaman yang melibatkan seluruh indera dan akan lama juga otak akan menyimpan dan akan lebih lama dan membekas dalam hati. Teori jerome S.bruner Tahap informasi (tahap penerimaanmateri ) Tahap transformasi (tahap pengubahan materi ) Tahap evaluasi.

Proses kognitif pada anak usia dini Anak dilahirkan dengan kecenderungan beradaptasi dan berorganisasi. Komponen adaptasi ada dua : Asimilasi yaitu kecenderungan organisme untuk mengubah lingkungan guna menyesuaikan dengan dirinya.. Akomodasi yaitu kecenderungan organisme untuk merubah dirinya sendiri untuk merubah dirinya sendiri guna menyesuaikan diri dengan kelilingnya. 
Perkembangan kognitif merupakan kemampuan anak untuk berpikir lebih komplek serta kemampuan melakukan penalaran dan pemecahan masalah yang termasuk dalam proses psikologis yang berkaitan dengan bagaimana individu mempelajari lingkungannya.

Belajar kognitif adalah tindakan mengenal atau memikirkan situasi dimana tingkah laku itu terjadi. Aktifitas belajar pada diri manusia ditekankan pada proses internal berpikir. Perkembangan kognitif pada anak merupakan suatu pembahasan yang sangat penting, karena merupakan kemampuan anak untuk brpikir lebih komplek serta kemampuan melakukan penalaran dan pemecahan masalah yang termasuk dalam proses psikologis yang berkaitan dengan bagaimana individu mempelajari lingkungannya.

Kemampuan anak dalam mengenal warna juga dipengaruhi fokus penglihatan anak saat mengikuti kegiatan pengenalan warna. Salah satunya adalah peran guru dalam mengenalkan warna pada anak. Seperti pendapat Rasyid, dkk, bahwa konsentrasi penglihatan anak usia dini dalam melihat suatu obyek diperlukan frekuensi yang berulang kali, sensitifitas benda yang dilihat, intensitas warna yang dilihat, efektivitas penglihatan anak, serta durasi atau lamanya waktu yang digunakan untuk melihat obyek benda itu.[5]

Dalam memahami dunia anak secara aktif, biasanya menggunakan skema (kerangka kognitif).Sebuah skema adalah konsep didalam pikiran individu yang dipakai untuk mengorganisasikan dan menginterprestasikan informasi.[9] Sedangkan proses kognitif, menggambarkan perubahan dalam pikiran, intelegensi, dan bahasa seseorang. Dan yang terakhir, proses sosial-emosi, melibatkan perubahan dalam hubungan dengan seseorang dengan orang lain, perubahan emosi, dan perubahan dalam kepribadian.[10]

Kedudukan seorang pendidik dalam mengembangkan media untuk mengembangkan kognitif anak memang sangat strategis dan menentukan. Strategis karena pendidik akan menentukan kedalaman dan 
keluasan pengembangan media yang dibutuhkan dalam suatu materi pembelajaran. Menentukan karena pendidiklah yang memlih dan memilah bahan pembelajaran yang akan disajikan kepada anak dalam berbagai bentuk media.[11]

Permainan yang dilalukan pada program terapi bermain ketika tim melakukan English fun adalah dengan bermain konstruktif lego. Lego adalah permaian konstruktif yang dapat membantu mengembangkan kemampuan kognitif anak.[12] Selain dengan lego, kami juga bermain game tebak gambar melalui kartu bergambar. Bermain game bisa bermanfaat bagi perkembangan kognitif anak, seperti meningkatkan keterampilan hingga kecepatan otak.[13]

\section{SARAN}

Upaya peningkatan kemampuan kognitif dengan metode terapi bermain dalam bahasa inggris pada anak TKIT Cahaya Ummat bisa dilanjutkan untuk di masukkan ke kurikulum tambahan atau kurikulum ekstra sehingga dapat meningkatkan kemampuan kognitif anak dan kreatifitas anak.

\section{DAFTAR PUSTAKA}

1. Setiyaningrum, E. 2017. Buku ajar Tumbuh Kembang Anak Usia 1-12 Tahun. Edisi Pertama. Indomedia Pustaka. Sidoarjo.

2. Ratnaningsih, T, Indatul, S \& Peni, T . 2017. Buku Ajar (Teori dan Konsep) Tumbuh Kembang dan Stimulasi. Edisi Pertama. Indomedia Pustaka. Sidoarjo.

3. Alupan, HD. Yudiernawati. A \& Susmini. 2017. Pengaruh Bermain Education Game Computer terhadap Perkembangan Kognitif pada Anak Usia Prasekolah di TK Shining Star Malang. Nursing News. Volume 2. Nomor 1.2017. Di Akses 10 Oktober 2019

4. Musfiroh, T. 2017. Modul 1 Teori Dan Konsep Bermain. Bermain dan Permainan Anak. PAUD4201/MODUL 
5. Rasyid,Harun Mansyur, \& Suratno. 2009. Asesmen Perkembangan Anak Usia Dini Yogyakarta: Multi Pressindo

6. Cohen, David. 2019. The Development Play. Fourth Edition Publised.London and New York

7. Suhazli, A., Atthariq, A., \& Anwar, A. (2017). Game Puzzle "Numbers in English"Berbasis Android Dengan Metode Fisher Yates Shuffle Sebagai Pengacak Potongan Gambar. Jurnal Infomedia. https://doi.org/10.30811/.v2i1.476.

8. Khadijah, 2016. Pengembangan Kognitif Anak Usia Dini. Perdana Publising. Kelompok Penerbit Perdana Mulya Sarana (IKPI). Cetakan Pertama. ISBN 978-602-6970-78-7

9. Nayazik, A., Suwignyo, J., \& Meidika, F. (2019). Peningkatan Kemampuan Kognitif Dalam Mengurutkan Lambang Bilangan Melalui Media Kartu Angka. Scholaria: Jurnal Pendidikan Dan Kebudayaan. https://doi.org/10.24246/j.js.2019.v9.i2.p160-171

10. Fauziddin, M. (2016). Meningkatkan Kemampuan Kognitif Anak melalui Kegiatan Membilang dengan Metode Bermain Media Kartu Angka. AUDI, 1(2), 60-70.

11. Ratnasari.R.,Utami. N.W,\&Rosdiana. Y.2017. Hubungan Bermain Megenal Warna dengan Perkembangan Kognitif Anak Usia Prasekolah di TK Dharma Wanita Kelurahan Tlogomas Kecamatan Lowokwaru Kota Malang.Nursing News Volume 2, Nomor 2, 2017.file:///C:/Users/User/Downloads/495-587-1-SM.pdf

12. Utami.S, Qur'aniati.N, Kusuma. E.R. 2017. Bermain Lego Meningkatan Perkembangan Kognitif Anak Usia Prasekolah (4-5 Tahun). e-journal.unair.ac.id, JNERS, article, download. file:///C:/Users/User/Downloads/4993-14465-1-SM.pdf. Di akses 15 Maret 2020.

13. Faradela.F. 2019."Manfaat Bermain Game Bagi Perkembangan Kognitif Anak", https://tirto.id/dhmP. Di akses 15 Maret 2020. 